\title{
Influence of camera-trap sampling design on mammal species capture rates and community structures in southeastern Brazil
}

\author{
Ana Carolina Srbek-Araujo ${ }^{1,2,4}$ \& Adriano Garcia Chiarello ${ }^{3}$ \\ ${ }^{1}$ Programa de Pós-graduação em Ecologia, Conservação e Manejo de Vida Silvestre, \\ Instituto de Ciências Biológicas, Universidade Federal de Minas Gerais - UFMG, \\ Av. Antônio Carlos, 6627, Pampulha, CEP 31270-901, Belo Horizonte, MG, Brazil \\ ${ }^{2}$ Vale S.A. / Reserva Natura Vale - Centro, CP 91, CEP 29900-970, Linhares, ES, Brazil \\ ${ }^{3}$ Departamento de Biologia, Faculdade de Filosofia Ciências e Letras de Ribeirão Preto, \\ Universidade de São Paulo - USP, Av. dos Bandeirantes, 3900, CEP 14040-901, Ribeirão Preto, SP, Brazil \\ ${ }^{4}$ Corresponding author: Ana Carolina Srbek-Araujo, e-mail: srbekaraujo@hotmail.com
}

SRBEK-ARAUJO, A.C. \& CHIARELLO, A.G. Influence of camera-trap sampling design on mammal species capture rates and community structures in southeastern Brazil. Biota Neotrop. 13(2): http://www. biotaneotropica.org.br/v13n2/en/abstract?article+bn02013022013

\begin{abstract}
The distribution of species and population attributes are critical data for biodiversity conservation. As a tool for obtaining such data, camera traps have become increasingly common throughout the world. However, there are disagreements on how camera-trap records should be used due to imperfect species detectability and limitations regarding the use of capture rates as surrogates for abundance. We evaluated variations in the capture rates and community structures of mammals in camera-trap surveys using four different sampling designs. The camera traps were installed on internal roads (in the first and fourth years of the study), at 100-200 m from roads (internal edges; second year) and at $500 \mathrm{~m}$ from the nearest internal road (forest interior; third year). The mammal communities sampled in the internal edges and forest interior were similar to each other but differed significantly from those sampled on the roads. Furthermore, for most species, the number of records and the capture success varied widely among the four sampling designs. A further experiment showed that camera traps placed on the same tree trunk but facing in opposing directions also recorded few species in common. Our results demonstrated that presence or non-detection and capture rates vary among the different sampling designs. These differences resulted mostly from the habitat use and behavioral attributes of species in association with differences in sampling surveys, which resulted in differential detectability. We also recorded variations in the distribution of records per sampling point and at the same spot, evidencing the stochasticity associated with the camera-trap location and orientation. These findings reinforce that for species whose specimens cannot be individually identified, the capture rates should be best used as inputs for presence and detection analyses and for behavior inferences (regarding the preferential use of habitats and activity patterns, for example). Comparisons between capture rates or among relative abundance indices, even for the same species, should be made cautiously.
\end{abstract}

Keywords: Atlantic Forest, capture success, detection bias, detection probability, mammal inventory.

SRBEK-ARAUJO, A.C. \& CHIARELLO, A.G. Influência do desenho amostral na taxa de captura e na estrutura da comunidade de mamíferos registrada a partir de armadilhas fotográficas no sudeste do Brasil. Biota Neotrop. 13(2): http://www.biotaneotropica.org.br/v13n2/pt/abstract?article+bn02013022013

Resumo: A distribuição das espécies e os atributos das populações são dados críticos para a conservação da biodiversidade. Enquanto ferramenta para obtenção de tais dados, as armadilhas fotográficas tem se tornado cada vez mais comuns em estudos em todo o mundo. No entanto, há divergências sobre como os registros fotográficos devem ser utilizados devido a problemas de detectabilidade e limitações relacionadas ao uso das taxas de captura como substitutos de abundância. No presente estudo foram avaliadas variações na taxa de captura e na estrutura da comunidade de mamíferos registrada por meio de armadilhas fotográficas utilizando-se quatro diferentes desenhos amostrais. As armadilhas foram instaladas em estradas internas (primeiro e quarto anos), a 100-200 m de distância das estradas (bordas internas; segundo ano) e a $500 \mathrm{~m}$ da estrada mais próxima (interior da mata; terceiro ano). As comunidades de mamíferos amostradas em bordas internas e interior da floresta foram semelhantes entre si, mas diferiram significativamente daquelas amostradas em estradas. Além disso, para a maioria das espécies, o número de registros e o sucesso de captura variaram muito entre os quatro desenhos amostrais. A partir de um experimento desenvolvido paralelamente às amostragens, foi observado ainda que armadilhas fotográficas colocadas em um mesmo tronco de árvore, mas voltadas para direções opostas, registraram poucas espécies em comum. Nossos resultados demonstram que presença ou não detecção e taxas de captura variam entre diferentes desenhos de amostragem. Essas diferenças são atribuídas principalmente ao uso do habitat e atributos comportamentais das espécies, em associação com diferenças no desenho amostral, resultando em diferenças na detectabilidade. Foram também registradas variações na distribuição de registros entre pontos de amostragem e para o mesmo local, evidenciando a estocasticidade associada à localização e orientação das armadilhas. Esses 
dados reforçam que, para espécies cujos espécimes não podem ser individualmente identificados, os registros fotográficos são mais bem utilizados como insumo para análises de presença e detecção, assim como para obtenção de informações relacionadas a comportamento (uso preferencial de habitats e padrão de atividade, por exemplo). Comparações entre taxas de captura ou índices de abundância relativa, mesmo para a mesma espécie, devem ser realizadas com cautela.

Palavras-chave: Mata Atlântica, sucesso de captura, viés de detecção, probabilidade de detecção, inventário de mamiferos.

\section{Introduction}

The distributions of species and population abundance or density are critical data for planning and evaluating research priorities and strategies for biodiversity conservation. The quality of inventories depends on the ability of the surveying team and the adequacy of the procedures, particularly regarding the efficiency of the sampling methods used for each target group. Indeed, the methods used in mammal inventories are generally appropriate for collecting or observing only a fraction of species, given the morphological and behavioral diversity in this group (Voss \& Emmons 1996).

Failures to detect species are common errors in surveys and are related to the detection probability of each species $(\mathrm{Gu} \&$ Swihart 2004). The detection of mammals may vary depending on the animal's sex, age, social status (alpha or beta and resident or transient) and territoriality (Larrucea et al. 2007), the distribution of reproductive females, the local abundance of prey (Guil et al. 2010), intraspecific and interspecific interactions (Harmsen et al. 2010), human pressure and the physical environment (Guil et al. 2010). Furthermore, the seasonality of the species can change the intensity with which a given species is recorded (Yasuda 2004), and the capture rate is influenced by the temporal and seasonal activity patterns of the species (Larrucea et al. 2007). Differences in detectability among species also can be caused by relatively subtle differences in behavior (Harmsen et al. 2010). It is thus important to evaluate differences in capture efficiency to distinguish true absence from the non-detection of a species in mammal inventories (Jennelle et al. 2002). And detection is indicative of presence, but non-detection is not equivalent to absence (MacKenzie et al. 2002).

Camera traps have become increasingly common in studies conducted in several parts of the world, especially during the last decade. These devices have been widely used in mammal inventories and are especially effective for detecting elusive, cryptic and/or rare species (e.g., Srbek-Araujo \& Chiarello 2005, Tobler et al. 2008, Ahumada et al. 2011, Espartosa et al. 2011). In addition to this usual application, Carbone et al. (2001) consider that the use of indices to estimate the relative abundance of mammals would increase the use of this tool because only a small fraction of the species may have the individuals identified and studied using capture-recapture methods based on camera traps. However, these indices use the rates of camera-trap capture as the main input to estimate abundance (e.g., Carbone et al. 2001, O'Brien et al. 2003), and the variation in the detection probability of each species is not considered. Thus, for relative abundance indices to be useful, some authorities recommend the calibration of indices using camera trap data (Carbone et al. 2001) and the evaluation of the index accuracy (Diefenbach et al. 1994) to demonstrate the existence of a functional relationship between the index and the true value (Diefenbach et al. 1994). However, the calibration process is not trivial, and there is no firm consensus on the best strategy to follow (e.g., O'Brien et al. 2003, Rowcliffe et al. 2008, Rovero \& Marshall 2009).

Notwithstanding the increase in the popularity of camera traps, the imperfect detectability and the appropriate application of capture rates remain very important issues, particularly regarding the use of camera-trap records as surrogates for abundance and population density of species whose individuals cannot be identified (Carbone et al. 2001, 2002, Jennelle et al. 2002, Yasuda 2004, Larrucea et al. 2007, Srbek-Araujo \& Chiarello 2007, Rowcliffe et al. 2008, Rovero \& Marshall 2009, Harmsen et al. 2010). Despite these limitations and recommendations, the index of relative abundance, without calibration, obtained from the rate or frequency of capture has been widely used in camera-trap studies (e.g., Jácomo et al. 2004, O'Brien et al. 2003, Silveira et al. 2003, Trolle \& Kéry 2005, Weckel et al. 2006, Kasper et al. 2007, Rowcliffe et al. 2008, Rovero \& Marshall 2009), without consideration of the variations in species capture probability (Gu \& Swihart 2004). These issues are relevant and need to be better understood because camera-trap data have been used in management and conservation studies around the world, including ratings of the distribution and monitoring of threatened species.

In this study, we report the results of four years of cameratrapping inventories in a protected area of Atlantic Forest in Brazil. We evaluate the variation of mammal capture rates from each survey and the influence of the sampling design on the mammal community recorded. We also discuss whether the capture rates represent reliable inputs for relative abundance indices. We hypothesized that detection does not change significantly and that capture rates are similar for a given mammal species sampled in the same area among subsequent camera-trap surveys, despite differences in the sampling designs (null hypothesis). If this hypothesis is true, the sampling design does not interfere with the community recorded, and the capture rates could be considered sufficient input to calculate the relative abundance indices; therefore, the calibration of the indices may be overlooked.

\section{Material and Methods}

\section{Study area}

The study was conducted in Reserva Natural Vale (RNV; Vale Natural Reserve), which is located $30 \mathrm{~km}$ north of the Doce River between the municipalities of Linhares and Jaguare in the state of Espírito Santo, southeastern Brazil (1906' S, 39 $9^{\circ} 45^{\prime} \mathrm{W}$ and $\left.19^{\circ} 18^{\prime} \mathrm{S}, 40^{\circ} 19^{\prime} \mathrm{W}\right)$. The RNV ( 23,000 ha) encompasses approximately $5 \%$ of the remaining forest in the state (Fundação... \& Instituto... 2011) and is adjacent to the Reserva Biológica de Sooretama (RBS; Sooretama Biological Reserve: 24,250 ha).

The topography in RNV is relatively flat, with the elevation ranging between 28 and $65 \mathrm{~m}$ above sea level (Jesus \& Rolim 2005). The climate is tropical hot and humid (Awi, following the Köppen system) with wet summers (October to March) and dry winters (April to September) (Jesus \& Rolim 2005). The average annual temperature is $23.3{ }^{\circ} \mathrm{C}\left(14.8\right.$ and $34.2{ }^{\circ} \mathrm{C}$ average minimum and maximum, respectively). The average annual rainfall is $1,202 \mathrm{~mm}$, with high inter-annual variability (Jesus \& Rolim 2005). During the years of study, for example, the annual rainfall ranged from $857 \mathrm{~mm}$ (2007) to $1,638 \mathrm{~mm}$ (2006), and the average annual rainfall was $1,194 \mathrm{~mm}$. 
Most of the reserve is covered by dense lowland forest located on flat terrain (Tabuleiro Forest), classified as perennial seasonal forest (Jesus \& Rolim 2005). RNV has an internal system of unpaved roads (126 km in total length). These roads are approximately $4 \mathrm{~m}$ wide and were built decades ago to allow access to all parts of the reserve for reserve staff and authorized researchers only. The perimeter of $\mathrm{RNV}$ is irregularly shaped and is surrounded mostly by pastures and crops, especially fruit and coffee cultivation (Jesus \& Rolim 2005). In recent years, particularly after 2007 , there has been an increase in Eucalyptus plantations surrounding the reserve.

\section{Data collection}

The sampling designs used in the four years were designed primarily to meet the requirements for estimating jaguar (Panthera onca) abundance and density. We used four different sampling designs over approximately 48 months: June 2005 to June 2006 (first year or year 1); June 2006 to August 2007 (second year or year 2); August 2007 to October 2008 (third year or year 3); and June 2009 to February 2010 (fourth year or year 4). Cam Trakker game cameras (Cam Trak South Inc., USA) were used in the first year; in the other years, we used Tigrinus cameras (conventional model; Tigrinus Research Equipment, Brazil). Both brands of equipment have a passive infrared sensor and $35 \mathrm{~mm}$ cameras, which were loaded with 36-exposure / 200 or 400 ASA negative films. The camera traps were operated 24 hours/day, and the delay between photographs was set to 20 seconds. The equipments were checked every 30 days for cleaning and to replace the batteries and film. The camera traps were attached to tree trunks at approximately $45 \mathrm{~cm}$ above the ground. In the first year, all trapping stations contained a pair of cameras, and the units were installed facing each other. In the other years, we used only one camera trap per trapping station. No baits were used.

In the first year, the reserve was divided into three areas ("north", "south" and "west"), and sampling was conducted in each of these areas sequentially. In the remaining years, a fixed number of sampling points or trap stations were established throughout the whole area of the reserve (years 2 and 3 ) or in just the northern part of the reserve (year 4) (Figure 1). The cameras were installed on internal roads (in the first and fourth years), at 100-200 m from roads (internal edges; second year) and at $500 \mathrm{~m}$ from the nearest internal road (forest interior; third year). In years 2 and 3 , the sampling points were selected by searching for the presence of signs (such as footprints and animal trails or tracks) or odors indicating recent mammal activity. A narrow trail ( $\sim 1 \mathrm{~m}$ width) was opened to access the trap stations in the second and third years. The camera-trap sampling points were always set in the predominant type of forest existing in RNV (Tabuleiro Forest). The main differences among the sampling designs are summarized in Table 1.

In the second year, we set up a 30-day experiment to test whether two cameras installed at the same spot would result in the same list of species. For this experiment, we used 8 pairs of Tigrinus cameras (the year 2 sampling point or principal camera [C1] and an additional camera [C2]) scattered throughout RNV. Every pair of cameras was positioned on the same tree trunk but faced in opposing directions (one camera rotated 180 degrees from the other) and remained operational for 30 days. We directed both of the cameras from each pair at points with similar characteristics to minimize sampling differences related to habitat conditions (e.g., the presence of tracks and/or other signs of animal activity).

\section{Data analysis}

Each photograph taken by the camera traps was considered a record. However, when more than one photograph of the same species was obtained from the same trapping station within a period of 1 hour, only the first photograph was considered valid for analytical purposes. The sampling effort was calculated by multiplying the number of camera traps (or pairs of equipment in year 1) by the number of sampling days (the time between the first and last records in each month of sampling). The capture success was calculated by dividing the number of records by the sampling effort and multiplying the result by 100, as used in previous studies (e.g., Srbek-Araujo

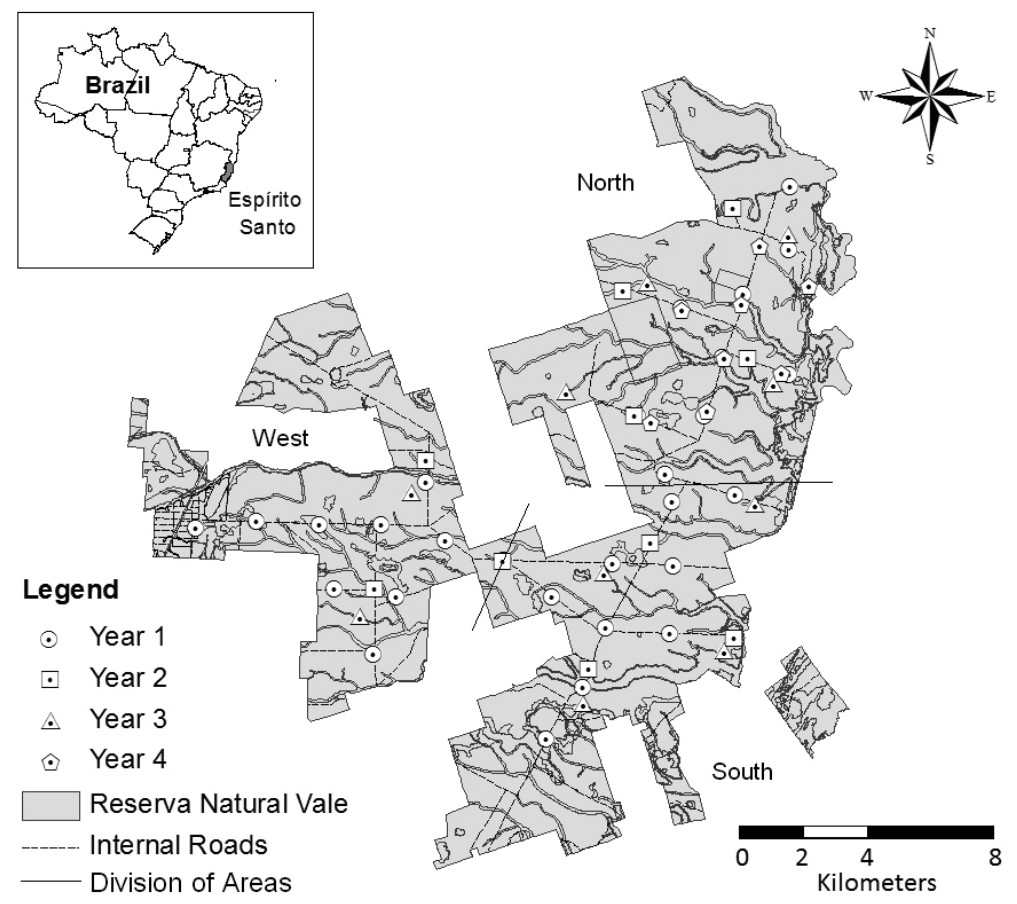

Figure 1. Reserva Natural Vale (Espírito Santo state) and locations of the camera traps in the four different sampling designs (June 2005 to February 2010). 
Table 1. Features of the sampling designs used in each year of the study in Reserva Natural Vale (June 2005 to February 2010 ).

\begin{tabular}{|c|c|c|c|c|c|c|}
\hline & $\begin{array}{l}\text { Sampling } \\
\text { coverage }\end{array}$ & $\begin{array}{c}\text { Camera } \\
\text { placement }\end{array}$ & $\begin{array}{c}\text { Number of } \\
\text { trapping stations }\end{array}$ & $\begin{array}{l}\text { Sampling duration } \\
\text { (number of months) }\end{array}$ & $\begin{array}{c}\text { Sampling time/ } \\
\text { sampling station }\end{array}$ & $\begin{array}{c}\text { Camera } \\
\text { spacing }(\mathbf{k m}) *\end{array}$ \\
\hline Year 1 & $\begin{array}{c}\text { Areas north, south } \\
\text { and west }\end{array}$ & Internal roads & 30 (10/area) & 12 & $\begin{array}{c}4 \text { months/area } \\
(2 \text { months/wet } \\
\text { season and } 2 \\
\text { months/dry season) }\end{array}$ & $2.35(1.96)$ \\
\hline Year 2 & $\begin{array}{l}\text { Areas north, } \\
\text { south and west }\end{array}$ & $\begin{array}{c}\text { Forest interior at } \\
100-200 \mathrm{~m} \text { from the } \\
\text { nearest internal road }\end{array}$ & 10 & 14 & Fixed & $4.40(4.05)$ \\
\hline Year 3 & $\begin{array}{l}\text { Areas north, } \\
\text { south and west }\end{array}$ & $\begin{array}{c}\text { Forest interior at } \\
500 \mathrm{~m} \text { from the } \\
\text { nearest internal road }\end{array}$ & 10 & 14 & Fixed & $5.14(3.93)$ \\
\hline Year 4 & Area north & Internal roads & 8 & 8 & Fixed & $2.31(1.75)$ \\
\hline
\end{tabular}

*Average distance between adjacent sampling points. The minimum spacing between cameras is shown in brackets.

\& Chiarello 2005). The armadillos Dasypus novemcinctus and Dasypus septemcinctus were analyzed together, as were the deer Mazama americana and Mazama gouazoubira, due to difficulties in distinguishing each congeneric species from most of the photographs. Only native species were considered in the statistical analyses.

The Mao Tau estimator (the accumulation of the observed species) was used to calculate randomized species accumulation curves considering 10-day bins of camera trapping as units of sampling effort. The lower and upper bounds of the $95 \%$ confidence interval (CI) were graphed. We used the first-order Jackknife (Jackknife 1) to estimate the species richness for each sampling design. This non-parametric estimator is based on the number of unique species contained in each observation (Smith \& Pontius 2006), and according to Tobler et al. (2008), it performs better than other estimators for data sets derived from large numbers of camera days. We also selected this estimator for its reduced bias and because it is based on the presence or absence of a species rather than on the abundance of the species (Smith \& Pontius 2006). For these analyses, we used the program EstimateS (version 7.5.2), and for randomizations, we used 1,000 runs.

The Spearman rank correlations and the qualitative cluster analysis (based on the Jaccard coefficient) were used to compare the mammal communities recorded by the four sampling designs $(n=27$ cases). Both of the analyses were performed using the presenceabsence data only (with values of " 1 " when a mammal species was detected by a sampling design and "0" when it was not). For these analyses, the program Statistica was used (version 7.1).

Given the differences in the sampling effort, we calculated the capture success of each mammal species ([number of records for each species / sampling effort] X 100) to obtain comparable capture rates for each species among the years. We used the Spearman rank test to investigate whether there were correlations in the capture rates of each species among the sampling designs. For this analysis, only species recorded in two or more years ( $\mathrm{n}=23$ cases) were included to reduce the occurrence of spurious correlations arising from the high frequency of zeros (four native species were detected in only one year). The tests were performed in the program Statistica (version 7.1).

We assessed the variation in capture success among the sampling designs by calculating the $95 \% \mathrm{CI}$ for each species. For this analysis, each sampling point was considered a replicate of a given sampling year, and the capture success of each species was calculated for every sampling point from each year of study. The program SPSS (version 8.0) was used for this analysis. And the results were displayed graphically to species with more contrasting detection rates (more than 10 records for the whole study). We complemented this analysis by contrasting the capture success of each species among the sampling designs using a Kruskal-Wallis one-way analysis of variance. For these analyses, the capture success values of each species were used as dependent variables, using the sampling points as replicates ( $n=58$ cases), and the years of sampling were the grouping variable (categorical). Only the species recorded in two or more years $(n=23$ cases) were considered in the Kruskal-Wallis one-way analysis of variance. For these analyses, the program Statistica was used (version 7.1). The variation in the capture success was assessed because these data can be used as an indicative of variation in the capture or detection probability of species.

\section{Assumptions}

Because weather variation can influence the detection of mammals and therefore the camera-trap results, we conducted preliminary tests to evaluate whether the capture success was significantly influenced by the inter-annual variability in climate conditions. For this analysis, we correlated the monthly capture success of native mammal species with climate variables (i.e., average monthly rainfall, total monthly rainfall and average monthly temperature) using the Spearman rank correlation. Each year was analyzed separately, and only months with 30 days of sampling were considered (11 cases for year 1, 14 cases for years 2 and 3, and seven cases for year 4). These tests were performed in the program Statistica (version 7.1). We obtained climatic data from the Instituto Nacional de Pesquisas Espaciais (INPE; National Institute of Spatial Research), and the data were collected at a meteorological station located in Sooretama, the closest city to the study site. The results of these tests indicated no consistent pattern in the relation between the climate variables and capture success. Significant correlations (Spearman Rank, $\mathrm{p}<0.05$ ) between the climate variables (mostly for average monthly temperature) and capture success were observed for only 11 species $(40.74 \%)$, and most cases were restricted to one year (nine species). For two species, there were significant correlations (Spearman Rank, $\mathrm{p}<0.05$ ) for two years, but for one of those species, the correlation between the average monthly temperature and capture success was positive in one year and negative in the other year. These results suggest a small influence of annual climate variation on the capture rates and leave us comfortable in assuming that the variations in our cameratrap data result mostly from differences among the sample designs.

Another limitation of our sampling design is that due to the theft of equipment and maintenance problems of some of the units, we had to choose a different brand of cameras in the second year. We are aware that variations in the efficiency and capability to record species among different brands or models of camera traps can influence the results (Srbek-Araujo \& Chiarello 2007), particularly when film and digital cameras are compared (Kelly \& Holub 2008). Because of that 
influence, it might be difficult to distinguish whether the variation in the number of records in a given survey is due to differences in trapping success among species or among the cameras (Kelly \& Holub 2008). Fortunately, only film cameras were used in our study, and the differences between the equipment are relevant only to year 1 , when Cam Trakker cameras were used, but not the other years (including the 30-day experiment), when only Tigrinus cameras were used. It is also relevant to stress that overall, the results from the first and fourth years were more similar to each other than to the second and third years, though different brands of cameras were used. For these reasons, we assumed that the use of two brands of cameras had no significant influence on our main findings.

\section{Results}

The sampling effort accumulated during the four years of study (10,567 camera-days) resulted in 2,790 records of 30 mammal species, including the domestic dog (Canis lupus familiaris) (Table 2).
Although the number of recorded species was similar among the sampling designs (19 to 23 species), the capture success was lower in the first and fourth years, when the cameras were located along roads. The community composition also varied among the sampling designs: 12 species $(40.0 \%)$ were recorded in all four designs; four species $(13.3 \%)$ were recorded in three designs; nine species $(30.0 \%)$ were recorded in two designs; and five species (16.7\%) were recorded in only one design. Six species $(20.0 \%)$ were recorded only on roads, and four $(13.3 \%)$ were recorded only on internal edges and/or in the forest interior. Some of the species recorded frequently along roads were rarely or not at all recorded when the cameras were set up away from roads, especially Panthera onca, Leopardus pardalis, Cerdocyon thous, Procyon cancrivorus and Sylvilagus brasiliensis (Table 2). In contrast, some species were recorded mostly away from roads: Dasypus sp., Nasua nasua, Pecari tajacu, Mazama sp., Cuniculus paca and Dasyprocta leporina.

Records of species not previously photographed occurred in all of the sampling periods, and the last inclusion of new species occurred in

Table 2. Number of records (n) and capture success (CS) for each mammal species recorded by four camera trapping sampling designs in Reserva Natural Vale (June 2005 to February 2010). The species richness, sampling effort (camera-days) and total capture success are also shown for each sampling design separately and in total.

\begin{tabular}{|c|c|c|c|c|c|c|c|c|c|c|}
\hline \multirow[t]{2}{*}{ Order } & \multirow[t]{2}{*}{ Species } & \multicolumn{2}{|c|}{$\begin{array}{c}\text { Year } 1 \\
\text { (roads) }\end{array}$} & \multicolumn{2}{|c|}{$\begin{array}{c}\text { Year } 2 \\
\text { (internal edges) }\end{array}$} & \multicolumn{2}{|c|}{$\begin{array}{c}\text { Year } 3 \\
\text { (forest interior) }\end{array}$} & \multicolumn{2}{|c|}{$\begin{array}{c}\text { Year } 4 \\
\text { (roads) }\end{array}$} & \multirow[t]{2}{*}{ Total } \\
\hline & & $\mathbf{n}$ & CS & $\mathbf{n}$ & CS & $\mathbf{n}$ & CS & $\mathbf{n}$ & CS & \\
\hline \multirow[t]{2}{*}{ Didelphimorphia } & Didelphis aurita (Wied-Neuwied, 1826) & 5 & 0.16 & 21 & 0.61 & 3 & 0.10 & 14 & 1.36 & 43 \\
\hline & Metachirus nudicaudatus (Desmarest, 1817) & & & 7 & 0.20 & & & & & 7 \\
\hline \multirow[t]{3}{*}{ Cingulata } & Cabassous tatouay (Desmarest, 1804) & & & 1 & 0.03 & & & 1 & 0.10 & 2 \\
\hline & Dasypus sp. (Linnaeus, 1758)a & 10 & 0.33 & 74 & 2.13 & 38 & 1.25 & 11 & 1.06 & 133 \\
\hline & Euphractus sexcinctus (Linnaeus, 1758) & 1 & 0.03 & & & 1 & 0.03 & & & 2 \\
\hline Pilosa & Tamandua tetradactyla (Linnaeus, 1758) & & & 1 & 0.03 & & & 1 & 0.10 & 2 \\
\hline \multirow[t]{2}{*}{ Primates } & Callithrix geoffroyi (Humboldt, 1812) & & & & & & & 1 & 0.10 & 1 \\
\hline & Sapajus robustus (Kuhl, 1820) & & & 2 & 0.06 & & & 3 & 0.29 & 5 \\
\hline \multirow[t]{11}{*}{ Carnivora } & Canis lupus familiaris (Linnaeus, 1758) & 2 & 0.07 & & & & & & & 2 \\
\hline & Cerdocyon thous (Linnaeus, 1766) & 24 & 0.79 & & & & & 34 & 3.29 & 58 \\
\hline & Galictis cuja (Molina, 1782) & & & & & & & 1 & 0.10 & 1 \\
\hline & Nasua nasua (Linnaeus, 1766) & 17 & 0.56 & 71 & 2.05 & 47 & 1.55 & 1 & 0.10 & 136 \\
\hline & Procyon cancrivorus (G. Cuvier, 1798) & 17 & 0.56 & & & & & 1 & 0.10 & 18 \\
\hline & Eira barbara (Linnaeus, 1758) & & & 7 & 0.20 & 3 & 0.10 & & & 10 \\
\hline & Leopardus pardalis (Linnaeus, 1758) & 67 & 2.21 & 13 & 0.37 & 5 & 0.16 & 16 & 1.55 & 101 \\
\hline & Leopardus wiedii (Schinz, 1821) & & & 1 & 0.03 & 2 & 0.07 & 2 & 0.19 & 5 \\
\hline & Panthera onca (Linnaeus, 1758) & 80 & 2.64 & 3 & 0.09 & 2 & 0.07 & 32 & 3.10 & 117 \\
\hline & Puma concolor (Linnaeus, 1771) & & & & & 1 & 0.03 & & & 1 \\
\hline & Puma yagouaroundi (É. Geoffroy, 1803) & 3 & 0.10 & 9 & 0.26 & 3 & 0.10 & 4 & 0.39 & 19 \\
\hline Perissodactyla & Tapirus terrestris (Linnaeus, 1758) & 68 & 2.24 & 51 & 1.47 & 50 & 1.65 & 8 & 0.77 & 177 \\
\hline \multirow[t]{3}{*}{ Artiodactyla } & Tayassu pecari (Link, 1795) & 5 & 0.16 & 2 & 0.06 & 3 & 0.10 & & & 10 \\
\hline & Pecari tajacu (Linnaeus, 1758) & & & 51 & 1.47 & 46 & 1.52 & 2 & 0.19 & 99 \\
\hline & Mazama sp. (Rafinesque, 1817) ${ }^{\mathrm{b}}$ & 57 & 1.88 & 378 & 10.90 & 563 & 18.56 & 34 & 3.29 & 1,032 \\
\hline \multirow[t]{4}{*}{ Rodentia } & Guerlinguetus ingrami (Thomas, 1901) & & & 16 & 0.46 & 17 & 0.56 & & & 33 \\
\hline & Hydrochoerus hydrochaeris (Linnaeus, 1766) & 5 & 0.16 & & & 2 & 0.07 & 3 & 0.29 & 10 \\
\hline & Cuniculus paca (Linnaeus, 1766) & 4 & 0.13 & 194 & 5.59 & 91 & 3.00 & 18 & 1.74 & 307 \\
\hline & Dasyprocta leporina (Linnaeus, 1758) & 16 & 0.53 & 231 & 6.66 & 152 & 5.01 & 16 & 1.55 & 415 \\
\hline Lagomorpha & Sylvilagus brasiliensis (Linnaeus, 1758) & 42 & 1.39 & & & & & 2 & 0.19 & 44 \\
\hline \multicolumn{2}{|c|}{ Number of Records } & \multicolumn{2}{|c|}{423} & \multicolumn{2}{|c|}{1,133} & \multicolumn{2}{|c|}{1,029} & \multicolumn{2}{|c|}{205} & 2,790 \\
\hline \multicolumn{2}{|c|}{ Number of Species } & \multicolumn{2}{|c|}{$17(19)$} & \multicolumn{2}{|c|}{$19(21)$} & \multicolumn{2}{|c|}{$18(20)$} & \multicolumn{2}{|c|}{$21(23)$} & $28(30)$ \\
\hline \multicolumn{2}{|l|}{ Sampling Effort } & \multicolumn{2}{|c|}{3,032} & \multicolumn{2}{|c|}{3,468} & \multicolumn{2}{|c|}{3,034} & & 33 & 10,567 \\
\hline Capture Success & & & 95 & & & & & & & 26.40 \\
\hline
\end{tabular}

${ }^{a}$ Dasypus novemcinctus (Linnaeus, 1758) and Dasypus septemcinctus (Linnaeus, 1758). ${ }^{\mathrm{b}}$ Mazama americana (Erxleben, 1777) and Mazama gouazoubira (G. Fischer, 1814). 
the $43^{\text {rd }}$ month of the study. The sample-based species accumulation curve for the first year leveled off, indicating a more complete survey (Figure 2), although the number of recorded species was much lower than the total number of observed species for the whole study. The curves for the other three years of sampling, as well as the curve for the whole study, did not reach an asymptote and showed a wide $95 \%$ $\mathrm{CI}$ interval (Figure 2). Wider confidence intervals were observed for years 2 and 4 .

The species richness estimated using the whole data set (all four years) was $29.98 \pm 1.71$ species, which is similar to the observed richness ( $\mathrm{n}=29$ native species). The estimated richness was also similar to the observed richness in the third year $(19.95[ \pm 1.36]$
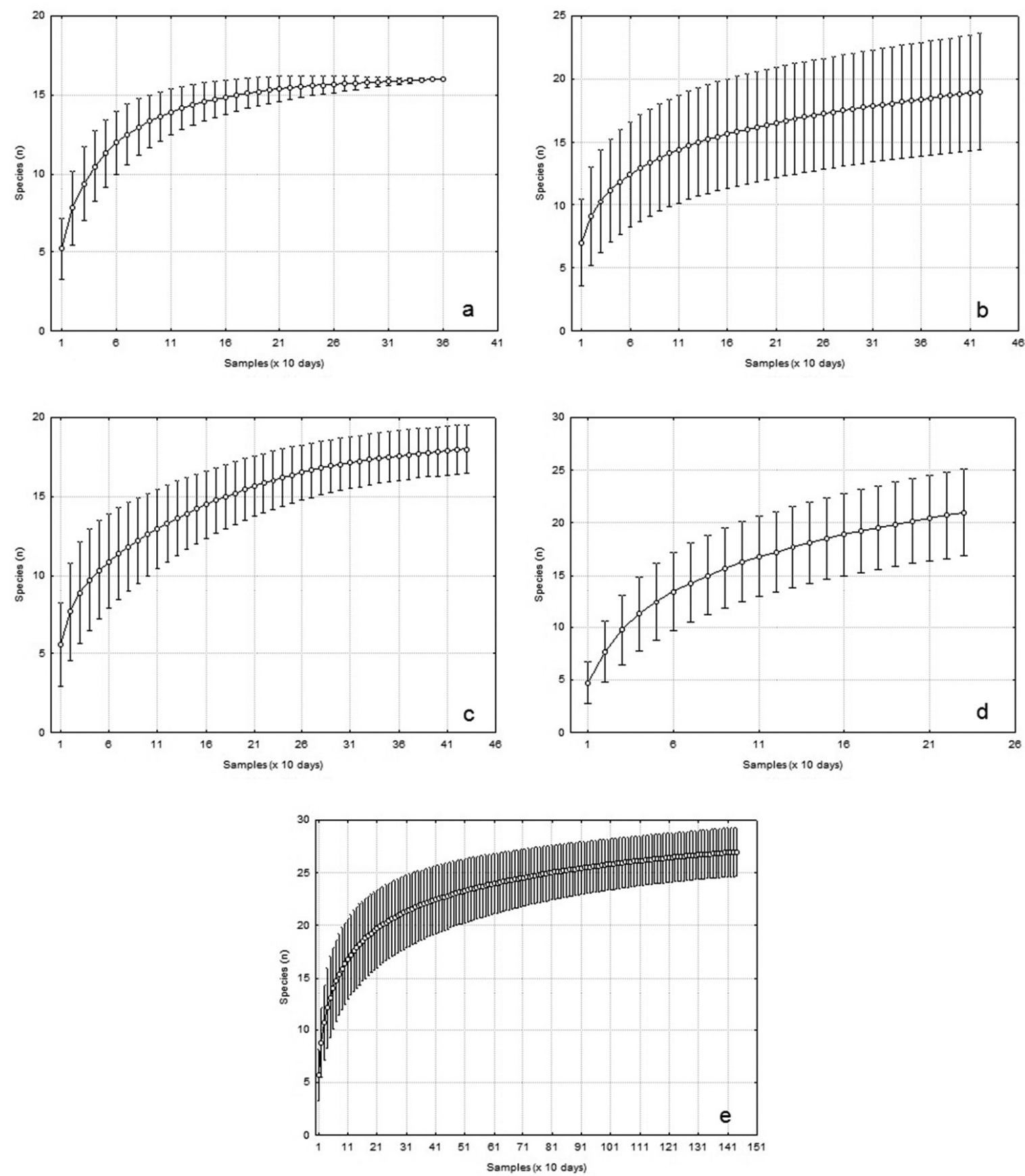

Figure 2. Sample-based species-accumulation curves (Mao Tau estimator) for the mammal species recorded during camera trapping surveys in Reserva Natural Vale (June 2005 to February 2010), including the lower and upper bounds of the 95\% CI: year 1 (a), year 2 (b), year 3 (c), year 4 (d) and the whole study (e). Each sampling unit ( $\mathrm{x}$ axis) represents 10 camera-days. 


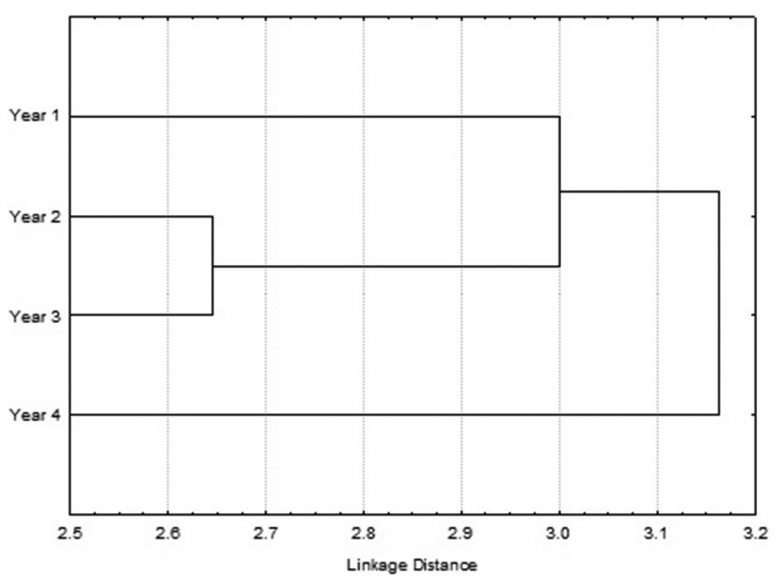

Figure 3. Dendrogram produced by the cluster analyses of the presence/ absence data (Jaccard coefficient) of the species recorded by the camera traps in the four sampling designs in Reserva Natural Vale (June 2005 to February 2010).

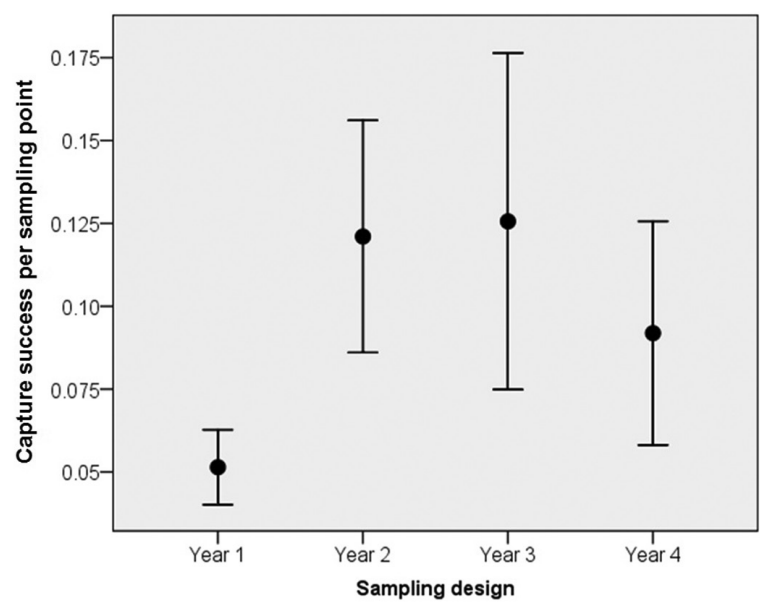

Figure 4. Means and confidence intervals (95\% CI) of the capture success per sampling point for each camera trap design in Reserva Natural Vale (June 2005 to February 2010). which was closer to the first year (with the samplings on roads) than to the other two years (Figure 3). Similarly, the distribution of the capture success in the set of species recorded was highly correlated between the first and fourth years (Spearman Rank, rs $=0.588$, $\mathrm{p}<0.05, \mathrm{n}=23$ pairs) and between the second and third years (Spearman Rank, $\mathrm{rs}=0.914, \mathrm{p}<0.05, \mathrm{n}=23$ pairs).

Although the results from the internal edges (second year) and forest interior (third year) were more similar to each other, the capture rate (and therefore the capture success) for most species varied among the years (Table 2). The same pattern was also found between the first and fourth years. Overall, the variation in capture success tended to be lower for the first year (with a smaller confidence interval and higher precision), but this parameter varied widely both within species among years and among species within years (Figure 4). For several species, the $95 \%$ CI showed no overlap among the sample designs, notably for Dasypus sp., Nasua nasua, Leopardus pardalis, Panthera onca, Mazama sp., Dasyprocta leporina and Cuniculus paca (Figure 5). Additionally, the difference in capture success among the sampling designs was statistically significant for 14 species (Kruskal-Wallis, $\mathrm{df}=3, \mathrm{n}=58$ cases, $\mathrm{p} \leq 0.05$ ) (Table 3 ). The number of species recorded at each sampling point ranged from 1 to 15 (mean $=6.86)$, and the total number of records for the trap stations ranged from 1 to $201($ mean $=48.07)$. When analyzing each species separately, the distribution of records among the sampling points was also variable, even for the species with the highest number of records in each sampling year (Table 3).

During the 30-day experiment, the number of species recorded by both of the cameras $(\mathrm{C} 1+\mathrm{C} 2)$ and the interceptions of records from each pair were very low (Table 4). Only the units from three pairs $(37.5 \%)$ shared $50 \%$ or more of the list of species recorded by the pair. For the remaining five pairs $(62.5 \%)$, each unit shared $\leq 25 \%$ of the species pool (Table 4). Four species (Eira barbara, Nasua nasua, Panthera onca and Puma yagouaroundi) were recorded during the 30-day experiment only by the additional unit (C2) and were not recorded by the principal camera $(\mathrm{C} 1)$ even during the 14 months of sampling by this unit. Discrepancies were also observed between units of each pair when compared the total number of records of each species and the overall number of records (sum of the records from all the species).
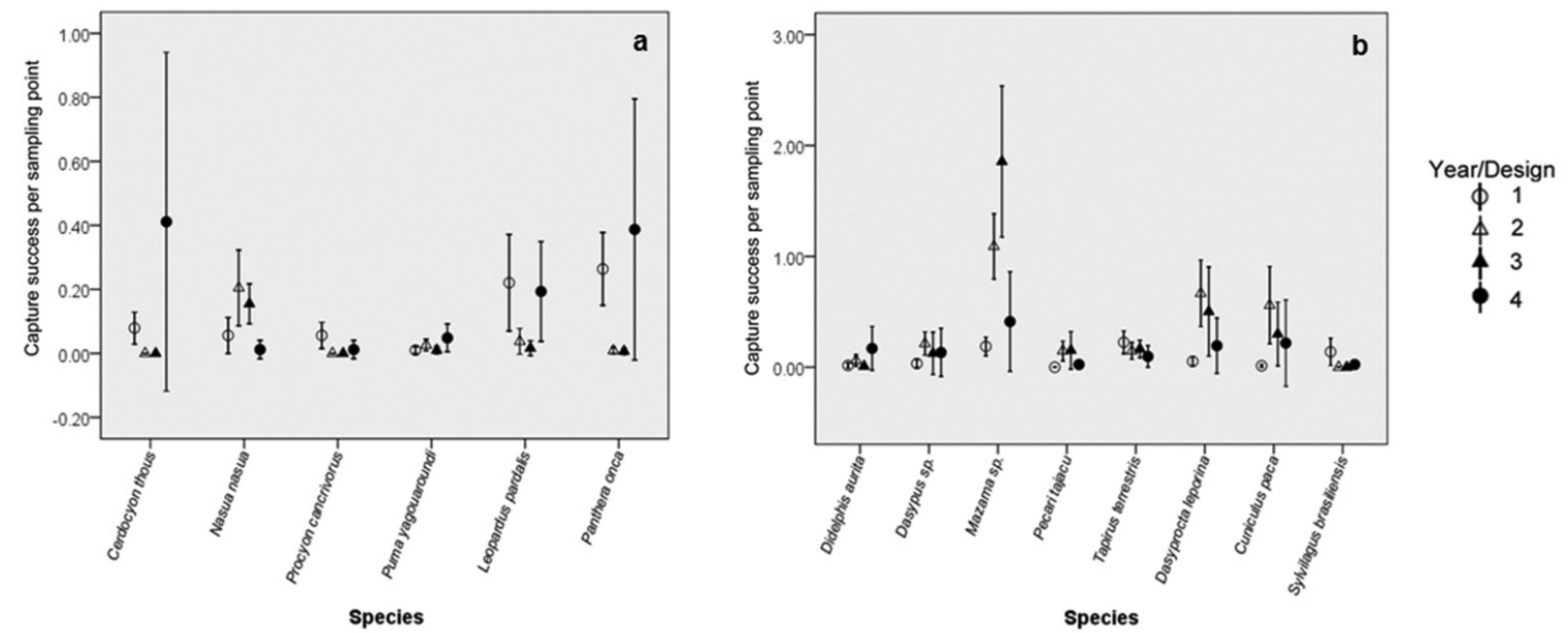

Figure 5. Means and confidence intervals (95\% CI) of the capture success per sampling point for Carnivora species (Families Canidae, Procyonidae and Felidae) (a) and other Orders (Families Didelphidae, Dasypodidae, Tayassuidae, Cervidae, Tapiridae, Dasyproctidae, Cuniculidae and Leporidae) (b) recorded in four camera trap designs in Reserva Natural Vale (June 2005 to February 2010). 
Table 3. Number of sampling points (p), amplitude of records per trap station (am) and average number of records per sampling point (av) for each of the mammal species recorded using four camera trapping sampling designs in Reserva Natural Vale (June 2005 to February 2010). Kruskal-Wallis one-way analysis of variance results are also shown for each species tested ( $\mathrm{df}=3, \mathrm{n}=58$ cases $)$.

\begin{tabular}{|c|c|c|c|c|c|c|c|c|c|c|c|c|c|}
\hline \multirow{2}{*}{ Species } & \multicolumn{3}{|c|}{ Year 1} & \multicolumn{3}{|c|}{ Year 2} & \multicolumn{3}{|c|}{ Year 3} & \multicolumn{3}{|c|}{ Year 4} & \multirow{2}{*}{ Kruskal-Wallis } \\
\hline & $\mathbf{p}$ & am & av & $\mathbf{p}$ & am & av & $\mathbf{p}$ & am & Av & p & am & av & \\
\hline C. tatouay & - & - & - & 1 & 1 & 1.00 & - & - & - & 1 & 1 & 1.00 & $\mathrm{H}=4.6318, \mathrm{p}=0.201$ \\
\hline C. geoffroyi & - & - & - & - & - & - & - & - & - & 1 & 1 & 1.00 & - \\
\hline S. robustus & - & - & - & 1 & 2 & 2.00 & - & - & - & 1 & 3 & 3.00 & $\mathrm{H}=4.6318, \mathrm{p}=0.201$ \\
\hline C. thous & 10 & $1-4$ & 2.40 & - & - & & - & - & - & 4 & $2-18$ & 8.50 & $\mathrm{H}=11.103, \mathrm{p}=0.011$ \\
\hline C. paca & 4 & 1 & 1.00 & 10 & $1-50$ & 19.40 & 8 & $1-38$ & 11.38 & 4 & $1-14$ & 4.50 & $\mathrm{H}=30.3992, \mathrm{p}<0.001$ \\
\hline D. leporina & 6 & $1-4$ & 2.67 & 10 & $5-47$ & 23.10 & 10 & $1-58$ & 15.20 & 4 & $2-9$ & 4.00 & $\mathrm{H}=31.7385, \mathrm{p}<0.001$ \\
\hline Dasypus sp. & 4 & $1-4$ & 2.50 & 9 & $3-15$ & 8.22 & 5 & $1-26$ & 7.60 & 2 & $4-7$ & 5.50 & $\mathrm{H}=18.6732, \mathrm{p}<0.001$ \\
\hline D. aurita & 3 & $1-3$ & 1.67 & 7 & $1-8$ & 3.00 & 3 & 1 & 1.00 & 3 & $4-5$ & 4.67 & $\mathrm{H}=12.2507, \mathrm{p}=0.007$ \\
\hline E. barbara & - & - & - & 4 & $1-4$ & 1.75 & 2 & $1-2$ & 1.50 & - & - & - & $\mathrm{H}=14.2842, \mathrm{p}=0.003$ \\
\hline E. sexcinctus & 1 & 1 & 1.00 & - & - & - & 1 & 1 & 1.00 & - & - & - & $\mathrm{H}=1.8327, \mathrm{p}=0.608$ \\
\hline G. cuja & - & - & - & - & - & - & - & - & - & 1 & 1 & 1.00 & - \\
\hline H. hydrochaeris & 5 & 1 & 1.00 & - & - & - & 2 & 1 & 1.00 & 2 & $1-2$ & 1.50 & $\mathrm{H}=2.5263, \mathrm{p}=0.471$ \\
\hline L. pardalis & 18 & $1-21$ & 3.72 & 5 & $1-6$ & 2.60 & 3 & $1-3$ & 1.67 & 5 & $2-5$ & 3.20 & $\mathrm{H}=8.4012, \mathrm{p}=0.039$ \\
\hline L. wiedii & - & - & - & 1 & 1 & 1.00 & 2 & 1 & 1.00 & 2 & 1 & 1.00 & $\mathrm{H}=7.406, \mathrm{p}=0.060$ \\
\hline Mazama sp. & 19 & $1-8$ & 3.00 & 10 & $27-68$ & 37.80 & 10 & $14-92$ & 56.30 & 6 & $1-16$ & 5.67 & $\mathrm{H}=35.5118, \mathrm{p}<0.001$ \\
\hline M. nudicaudatus & - & - & - & 2 & $2-5$ & 3.50 & - & - & - & - & - & - & - \\
\hline N. nasua & 5 & $1-7$ & 3.40 & 10 & $1-20$ & 7.10 & 10 & $1-9$ & 4.70 & 1 & 1 & 1.00 & $\mathrm{H}=28.5303, \mathrm{p}<0.001$ \\
\hline P. onca & 24 & $1-14$ & 3.33 & 3 & 1 & 1.00 & 2 & 1 & 1.00 & 7 & $1-16$ & 4.57 & $\mathrm{H}=24.4249, \mathrm{p}<0.001$ \\
\hline P. tajacu & - & - & - & 10 & $1-11$ & 5.10 & 8 & $1-24$ & 5.75 & 2 & 1 & 1.00 & $\mathrm{H}=40.7603, \mathrm{p}<0.001$ \\
\hline P. cancrivorus & 9 & $1-5$ & 1.89 & - & - & - & - & - & - & 1 & 1 & 1.00 & $\mathrm{H}=7.9002, \mathrm{p}=0.048$ \\
\hline P. concolor & - & - & - & - & - & - & 1 & 1 & 1.00 & - & - & - & - \\
\hline P. yagouaroundi & 3 & 1 & 1.00 & 6 & $1-2$ & 1.50 & 3 & 1 & 1.00 & 4 & 1 & 1.00 & $H=9.2832, p=0.026$ \\
\hline G. ingrami & - & - & - & 5 & $1-9$ & 3.20 & 7 & $1-6$ & 2.43 & - & - & - & $\mathrm{H}=29.1555, \mathrm{p}<0.001$ \\
\hline S. brasiliensis & 8 & $1-15$ & 5.25 & - & - & - & - & - & - & 2 & 1 & 1.00 & $\mathrm{H}=6.3342, \mathrm{p}=0.096$ \\
\hline T. tetradactyla & - & - & - & 1 & 1 & 1.00 & - & - & - & 1 & 1 & 1.00 & $\mathrm{H}=4.6318, \mathrm{p}=0.201$ \\
\hline T. terrestris & 19 & $1-11$ & 3.58 & 2 & $1-4$ & 25.50 & 10 & $1-11$ & 5.00 & 4 & $1-3$ & 2.00 & $\mathrm{H}=2.6301, \mathrm{p}=0.452$ \\
\hline T. pecari & 5 & 1 & 1.00 & 2 & 1 & 1.00 & 3 & 1 & 1.00 & - & - & - & $\mathrm{H}=2.4932, \mathrm{p}=0.477$ \\
\hline
\end{tabular}

\section{Discussion}

We recorded substantial variations in the detection (presence or non-detection) and capture rates of mammals among the four sampling periods. Some species were missed in one or more years, and singular assemblages of elusive species ( $\leq 5$ records/species) were recorded in each of the four sampling designs. Some of these species maintain their "status" of elusive or rarely recorded even when the whole sampling period is considered, such as Cabassous tatouay, Euphractus sexcinctus, Tamandua tetradactyla, Puma concolor, Leopardus wiedii and Galictis cuja, and new species were recorded during all four years of study. According to Tobler et al. (2008), the recording of more elusive species requires larger sampling efforts, and these species are the ones that determine how much time is needed to complete an inventory (Tobler et al. 2008). In fact, despite the relatively long sampling time in the present study, the camera-trapping inventory of medium-sized and large mammals is not yet complete in RNV. Two elusive species recently recorded in the study area (after 2006) using other methods and potentially recordable by camera traps have not been registered to date: Priodontes maximus (Kerr, 1792) (giant armadillo; Srbek-Araujo et al. 2009) and Leopardus tigrinus (Schreber, 1775) (oncilla; A.C. Srbek-Araujo, unpublished data). The slope of the sample-based species accumulation curve and the $95 \% \mathrm{CI}$ interval for the whole study also corroborate the previous affirmation.

For MacKenzie \& Royle (2005), the optimal strategy for sampling rare species is to conduct fewer surveys at more sampling
Table 4. Number of species recorded by each camera separately (C1 and $\mathrm{C} 2)$, in total $(\mathrm{C} 1+\mathrm{C} 2)$ and the intersection of records (number of species [n] and percentage [\%] of the total species recorded) during the 30-day period from two cameras positioned on the same tree and facing opposite directions. The results from the pairs of cameras were arranged in increasing rate of intersection of records. See Methods for details.

\begin{tabular}{ccccccc}
\hline $\begin{array}{c}\text { Samples } \\
\text { (pairs) }\end{array}$ & \multicolumn{3}{c}{ Cameras } & & \multicolumn{2}{c}{ Intersection } \\
\cline { 2 - 4 } \cline { 5 - 6 } & $\mathbf{C 1}$ & $\mathbf{C 2}$ & $\mathbf{C 1 + C 2}$ & & $\mathbf{N}$ & \% \\
\hline 2 & 5 & 0 & 5 & & 0 & 0.0 \\
3 & 5 & 4 & 8 & & 1 & 12.5 \\
4 & 5 & 3 & 7 & & 1 \\
1 & 1 & 5 & 5 & & 1 & 20.0 \\
6 & 1 & 4 & 4 & & 25.0 \\
5 & 2 & 1 & 2 & & 50.0 \\
7 & 1 & 2 & 2 & & 50.0 \\
8 & 3 & 4 & 4 & 3 & 75.0 \\
Total & 12 & 11 & 15 & 8 & 53.3 \\
\hline
\end{tabular}

points, while for common species, it is more efficient to conduct more intensive surveys at fewer stations. However, Srbek-Araujo \& Chiarello (2007) showed that the number of recorded species (common and rare species) is strongly correlated with sampling effort, recommending a sampling effort of at least 250 camera-days at each trapping station for mammal inventories. Additionally, Tobler et al. 
(2008) concluded that the camera spacing and total area covered have little influence on the number of species recorded and the survey success, with the survey effort being the main factor determining the number of recorded species. Our present data corroborate these last two studies and reinforce the importance of survey effort for recording elusive or rare species in camera-trapping inventories. In contrast, in occupancy studies, the number of sampling points can be as or more important than the number of sampling days at each trap station (MacKenzie et al. 2002). However, for these studies, the sampling points and the timing of repeat surveys must be defined appropriately, as described by MacKenzie \& Royle (2005).

The total number of species recorded in each sampling survey was similar in years 1 to 3, despite the higher number of trap stations sampled during the first year. The sampling effort was almost three times smaller in year 4 than in the other years, with the smallest number of sampling points, but the number of species was higher in the last year of sampling than in the other three survey periods. All of the sampling surveys performed poorly at estimating the total number of species present across the whole study area, and the list of species recorded each year was different among the surveys. The different results among the years highlight that species inventories also need to achieve good spatial replication and cover a range of habitat types to adequately characterize a mammal community (Colwell \& Coddington 1994, Engeman 2005, Tobler et al. 2008). In addition to the differences related to the set of species recorded each year, the differences among the sampling designs are also represented by differences in the capture rate for most of the species recorded during the present study.

We consider that the differences in capture rates obtained for the same species during our study resulted mostly from habitat use (i.e., species presence and frequency of use) and the behavioral attributes of the species in association with differences in the sampling design, which resulted in differential detectability and different capture success. Different species were more likely to be recorded on or off roads/trails, corroborating studies conducted elsewhere (Trolle \& Kéry 2005, Srbek-Araujo \& Chiarello 2007, Harmsen et al. 2010, Weckel et al. 2006). Some species were detected exclusively or preferentially on roads (e.g., Panthera onca, Leopardus pardalis, Sylvilagus brasiliensis, Cerdocyon thous and Procyon cancrivorus) and can be referred to as "trail followers". Other taxa, the "generalist users", were detected equally on roads and away from them (Tapirus terrestris and Tayassu peccary). The remaining species, the "trail crossers", seemed to avoid roads and were mostly recorded on the forest edge or in the forest interior. These distinctions are relevant given that both roads and trails have been widely used for sampling mammals, either because they offer easy access into the forest or because some species, particularly carnivores, might be highly "captured" in these places (e.g., Silveira et al. 2003, Trolle \& Kéry 2005, Beisiegel 2009). Therefore, the risk of tendentious sampling must be considered when designing studies for mammal community inventories.

Furthermore, differences in patterns of habitat use may not be similar even when the same species is compared between sampling sites. In a study by Weckel et al. (2006), for example, Tayassu peccary and Pecari tajacu failed to show preferences in habitat use, while in our study, the latter species was recorded almost exclusively in the forest edge and interior. In the same study, Panthera onca was never photographed using forested areas (Weckel et al. 2006), while in RNV, jaguar was recorded, although rarely, on internal edges and forest interior. In our study, Panthera onca and Leopardus pardalis were frequently recorded on roads, and both species have low capture rates outside roads, while Puma concolor was captured only once and in forest interior. Harmsen et al. (2010) recorded Leopardus pardalis only on trails ( 0.5 to $4.5 \mathrm{~m}$ width) and the capture sites of Panthera onca were also adequate for capturing Puma concolor. Differences between our study and Harmsen et al. (2010) were also observed for Tayassu peccary, Mazama sp. and Nasua nasua regarding their tendency to follow or cross trails. These examples of differences between studies suggest idiosyncratic habitat use patterns for some mammal species, which can induce erroneous comparisons of data even when applied to similar sample designs. These data also corroborate those of Jennelle et al. (2002), who cited site-specific detection probabilities as one of the sources of variation in cameratrap data. Therefore, if individual species may have consistent differences in detectability in different areas, the survey designs should not automatically follow designs that have been useful in other areas, even for the same target species.

Environmental seasonality is known to influence the activity patterns and home-range size in mammals (Harestad \& Bunnel 1979). In turn, the variation in the intensity of movement of individuals may result in increased or decreased detection probabilities, thereby influencing the capture rates. However, there was a lack of significant correlation between climatic variables and capture success for most of the species recorded in the present study (see Methods for details), and the inter-annual variation in rainfall may have not contributed significantly to the variation in the capture rate among the years. Although camera traps are well suited to standardization when compared to other sampling methods for mammals (Ahumada et al. 2011), the places where the data are collected influences the efficiency in obtaining adequate measurements of species studied Engeman (2005), and the choices about where and when the camera traps will be placed can influence the sampling process. These choices can lead to biased results because species use the environment differently and researchers use different criteria to define the best sampling locations (Larrucea et al. 2007).

We observed a wide variation in the capture success at each sampling point, both within and among the sampling periods, for most of the species recorded at RNV. The 30-day experiment with paired cameras also revealed that the variation in camera-trap records may be high at the same spot. These data illustrate the stochasticity associated with camera location and orientation and lend support to the idea that there are other biotic or abiotic factors, not yet fully understood, influencing the delivery of camera-trap records and interfering with probability of detection of species over time. Similarly, Silveira et al. (2010) noticed that the "long-term" fluctuation in capture rate is more complex than the seasonal variation in the number of records obtained by camera traps. And there are not enough data to identify the source of these variations (Silveira et al. 2010). In another study, five of the 15 species recorded by Espartosa et al. (2011) were captured only by camera trapping or track counts using sampling units consisting of one camera trap and four sand plots set at $5 \mathrm{~m}$ around the camera. These findings corroborate our previous study (Srbek-Araujo \& Chiarello 2007), in which we suggested that factors intrinsic to the place at which the equipment was installed might influence the records obtained. Our results further exemplify how much variability can be present in camera-trap data, which can restrict the application of records and blur conclusions, even when the same sampling methods are used and similar sampling designs are applied. Because of that variability, researchers conducting camera-trap surveys in time series should try to ensure a consistent setup of cameras (e.g., leaving cameras in situ for a long time) to reduce the stochasticity effect.

Despite the set of factors influencing the detection probability of species (e.g., Yasuda 2004, Larrucea et al. 2007, Guil et al. 2010, Harmsen et al. 2010), there is a growing demand for the use of camera traps as a tool for estimating population parameters or monitoring the population tendencies of threatened species. When the same 
sampling survey is adopted, it is reasonable to evaluate the trend of camera-trap records against a detectable perturbation or impact (e.g., the start of hunting activities or the detection of pest animals), but it is necessary to determine whether the trends of decline or increase are real or whether they result from other sampling factors (Tomas \& Miranda 2003)

According to Johnson (2008), for the valid use of indices to detect changes in density or abundance, the variation in detectability needs to be substantially lower than the variation in population size. Based on this premise, imperfect detectability or changes in species detection can make the use of rates of camera-trap capture non-viable as surrogates of abundance estimates or inputs for relative abundance indices. The capture success calculated for each species in the present study, for example, which is similar to the index of relative abundance "RAI-2" described by O'Brien et al. (2003), varied highly among the sampling designs for almost all of the species. Furthermore, for several species, there was no overlap in capture success among years, and the capture rate varied in both directions (rise and decline) over consecutive years, with very large differences in values. However, we assumed that the mammal community structure did not change dramatically in RNV over the four years of study and, therefore, that the variation in capture success among years and survey designs has another source. In this sense, it is noteworthy that smaller mammals experience more dramatic seasonal declines in abundance than do larger mammals (Harestad \& Bunnel 1979). Additionally, variations in the abundance of medium and large mammal populations are not expected to occur as sudden events of high magnitude under stable environmental conditions (Vaughan et al. 2000). This pattern is reasonable to expect for RNV due to the existence of an effective surveillance system against poaching, logging and forest-fire intrusions. These activities help keep the local fauna and flora buffered against anthropogenic threats and disturbances, which currently occur at low intensities. Although changes in the abundance of mediumsize and large mammals may occur as a result of significant changes in the availability of food resources (e.g., Groot-Bruinderink et al. 1994) or intensive poaching (e.g., Chiarello 1999), for example, it is often difficult to detect population declines over relatively short periods, unless the rates are catastrophic (Tomas \& Miranda 2003). Furthermore, it is unlikely that the changes affect, in a short time, a comprehensive set of species with different ecological requirements and different levels of hunting pressure, with abrupt variations of abundance indices, as observed in the present study. Therefore, the variation in the specific capture success in RNV indicates a lack of real functional relationship between the camera-trapping rate and population abundance.

Our results provide further support to previous studies, indicating that detection is not similar for all species, neither in the same area nor between similar sampling designs (e.g., Tobler et al. 2008, Harmsen et al. 2010), which is aggravated by the stochasticity associated with the camera-trap location and orientation. Consequently, the capture rate obtained by camera traps is not standard and cannot be correlated with population size; therefore, the capture rate does not represent a precise input to assess the relative abundance of species without suitable data processing. To use the number of records in the evaluation of quantitative attributes of a species over time and among sampling sites, it is necessary to obtain comparable capture rates (Jennelle et al. 2002, Engeman 2005). To do so, we must ensure that the field protocols are standardized and simultaneously applied (Espartosa et al. 2011) and assume that the detection probability of target species is similar among the studied sites (Harmsen et al. 2010). Moreover, for abundance analyses, camera-trap surveys must conform to an appropriate sampling design (with adequate spatial and temporal replication) to produce indices with a useful level of precision (Engeman 2005), and the indices must be calibrated (Carbone et al. 2001). Otherwise, the use of photographic records per se for population inferences can lead to erroneous interpretations of the number of individuals composing the populations, leading to under- or over-estimates of the populations of species whose specimens cannot be individually identified.

The influence of habitat use on the detection probabilities and capture rates of mammals (e.g., Srbek-Araujo \& Chiarello 2005, Larrucea et al. 2007, Tobler et al. 2008, Harmsen et al. 2010) is one of the main sources of variation in camera-trap data, reinforcing the fact that comparisons of relative abundance indices between species should always be made with caution (Harmsen et al. 2010). The same caution should be applied to compare the same species in the same site or among areas based on similar or different sampling surveys. Corroborating the reports of other authors (Carbone et al. 2001, Jennelle et al. 2002, Srbek-Araujo \& Chiarello 2007, Harmsen et al. 2010), we recommend that data on the capture rates of species should only be used as a surrogate for abundance when the probability of detection of each taxon has been ascertained and the indices based on capture rates have been calibrated. If these tasks cannot be accomplished, we suggest that camera-trapping rates should be best used as inputs for presence and detection analyses and for behavior inferences (regarding the preferential use of habitats and activity patterns, for example). Alternatively, the camera-trap data from appropriate sampling designs could be used to estimate species occupancy, which may be used as a surrogate for abundance (MacKenzie et al. 2002, MacKenzie \& Royle 2005), as applied by Ahumada et al. (2011). When it is possible to distinguish individuals, camera-trap data can be used to estimate population parameters through the use of capture-recapture probabilistic models, as proposed by Karanth (1995) and Karanth \& Nichols (1998).

\section{Conclusions}

Our results indicate that the sampling design influences the mammal community recorded by camera traps, reinforcing that the risk of tendentious sampling must be taken into account when designing species inventories. The differences observed for the same species among the sampling years resulted mostly from habitat use and behavioral attributes in association with differences in the sampling design, which resulted in differential detectability and in different capture rates. We also observed a wide variation in the distribution of records per sampling point, within and among sampling periods, for most of the species recorded at RNV, and the variation in camera trap records may be high at the same spot. These data demonstrated the stochasticity associated with equipment location and orientation, reinforcing the idea that camera-trap surveys conducted in time series should try to ensure a consistent setup of cameras to reduce the stochasticity effect. The variation in specific capture success in RNV, at a high level and in both directions over consecutive years, indicates a lack of a real functional relationship between the camera-trapping rate and population abundance. Consequently, the use of rates of camera-trap capture per se for abundance inferences can lead to under- or over-estimates of the populations of mammalian species that are not individually identifiable.

\section{Acknowledgments}

The data in this paper are part of the research project "Population Size, Density and Habitat Use by Jaguar (Panthera onca, Carnivora, Felidae) in Reserva Natural Vale, Linhares, Espírito Santo / Brazil". We thank Vale S.A. / Instituto Ambiental Vale for their financial support. H.J. Del-Duque Junior, E.R. Coelho, B. Guerin and J. Simplício for their help with the field activities and E.C. Landau 
from Empresa Brasileira de Pesquisa Agropecuária (Embrapa) for the inestimable help with the climatic variables data. We thank anonymous reviewers for comments that helped to improve the paper. A. G. Chiarello is sponsored by CNPq (303273/2008-9 and 306848/2011-2).

\section{References}

AHUMADA, J.A., SILVA, C.E.F., GAJAPERSAD, K., HALlAM, C., HURTADO, J., MARTIN, E., MCWILLIAM, A., MUGERWA, B., O'BRIEN, T., ROVERO, F., SHEIL, D., SPIRONELLO, W.R., WINARNI, N. \& ANDELMAN, S.J. 2011. Community structure and diversity of tropical forest mammals: data from a global camera trap network. Philos. Trans. R. Soc. Lond., Ser. B 366:2703-2711. http:// dx.doi.org/10.1098/rstb.2011.0115

BEISIEGEL, B.M. 2009. First camera-trap record of bush dogs in the state of São Paulo, Brazil. Canid News 12.5. http://www.canids.org/canidnews/12/ Bush_dogs_in_Sao_Paulo.pdf(último acesso em 08/07/2010).

CARBONE, C., CHRISTIE, S., CONFORTI, K., COULSON, T., FRANKLIN, N., GINSBERG, J.R., GRIFFITHS, M., HOLDEN, J., KAWANISHI, K., KINNAIRD, M., LAIDLAW, R., LYNAM, A., MacDONALD, D.W., MARTYR, D., McDOUGAL, C., NATH, L., O'BRIEN, T.O., SEIDENSTICKER, J., SMITH, D.J.L., SUNQUIST, M., TILSON, R. \& WAN SHAHRUDDIN, W.N. 2001. The use of photographic rates to estimate densities of tigers and other cryptic mammals. Anim. Conserv. 4(1):75-79. http://dx.doi.org/10.1017/S1367943001001081

CARBONE, C., CHRISTIE, S., CONFORTI, K., COULSON, T., FRANKLIN, N., GINSBERG, J.R., GRIFFITHS, M., HOLDEN, J., KINNAIRD, M., LAIDLAW, R., LYNAM, A., MacDONALD, D.W., MARTYR, D., McDOUGAL, C., NATH, L., O'BRIEN, T.O., SEIDENSTICKER, J., SMITH, D.J.L., TILSON, R. \& WAN SHAHRUDDIN, W.N. 2002. The use of photographic rates to estimate densities of tigers and other cryptic mammals: response to Jennelle et al. Anim. Conserv. 5(2):121-132. http:// dx.doi.org/10.1017/S1367943002002172

CHIARELLO, A.G. 1999. Effects of fragmentation of the Atlantic Forest on mammal communities in south-eastern Brazil. Biol. Conserv. 89:71-82. http://dx.doi.org/10.1016/S0006-3207(98)00130-X

COLWELL, R.K. \& CODDINGTON, J.A. 1994. Estimating terrestrial biodiversity through extrapolation. Phil. Trans. R. Soc. Lond. 345:101118. http://dx.doi.org/10.1098/rstb.1994.0091

DIEFENBACH, D.R., CONROY, M.J., WARREN, R.J., JAMES, W., BAKER, L.A. \& HON, T. 1994. A test of the scent-station survey technique for bobcats. J. Wildl. Manage. 58:10-17. http://dx.doi.org/10.2307/3809543

ENGEMAN, R.M. 2005. Indexing principles and a widely applicable paradigm for indexing animal populations. Wildl. Res. 32:203-210. http:// dx.doi.org/10.1071/WR03120

ESPARTOSA, K.D., PINOTTI, B.T. \& PARDINI, R. 2011. Performance of camera trapping and track counts for surveying large mammals in rainforest remnants. Biodiv. Conserv. 20(12):2815-2829. http://dx.doi. org/10.1007/s10531-011-0110-4

FUNDAÇÃO SOS MATA ATLÂNTICA \& INSTITUTO NACIONAL DE PESQUISAS ESPACIAIS - INPE. 2011. Atlas dos Remanescentes Florestais da Mata Atlântica - Período 2008-2010. São Paulo. http:// mapas.sosma.org.br/site_media/download/atlas_2008-10_relatorio $\% 20$ final_versao2_julho2011.pdf (último acesso em 10/08/2012).

GROOT-BRUINDERINK, G.W.T.A., HAZEBROEK, E. \& VAN DER VOOT, H. 1994. Diet and condition of wild boar, Sus scrofa scrofa, without supplementary feeding. J. Zool. 233:631-648. http://dx.doi. org/10.1111/j.1469-7998.1994.tb05370.x

GU, W. \& SWIHART, R.K. 2004. Absent or undetected? Effects of nondetection of species occurrence on wildlife-habitat models. Biol. Conserv. 116:195-203. http://dx.doi.org/10.1016/S0006-3207(03)00190-3
GUIL, F., AGUDÍN, S., EL-KHADIR, N., FERNANDEZ-OLALLA, M., FIGUEREDO, J., DOMÍNGUEZ, F.G., GARZON, P., GONZALEZ, G., MUÑOZ-IGUALADA, J., ORIA, J. \& SILVESTRE, F. 2010. Factors conditioning the camera-trapping efficiency for the Iberian lynx (Lynx pardinus). Eur. J. Wildl. Res. 56(4):633-640. http://dx.doi.org/10.1007/ s10344-009-0353-5

HARESTAD, A.S. \& BUNNEL, F.L. 1979. Home Range and Body Weight--A Reevaluation. Ecology 60(2):389-402. http://dx.doi.org/10.2307/1937667

HARMSEN, B.J., FOSTER, R.J., SILVER, S., OSTRO, L. \& DONCASTER, C.P. 2010. Differential Use of Trails by Forest Mammals and the Implications for Camera-Trap Studies: A Case Study from Belize. Biotropica 42(1):126-133. http://dx.doi.org/10.1111/j.17447429.2009.00544.x

JÁCOMO, A.T.A., SILVEIRA, L. \& DINIZ-FILHO, J.A.F. 2004. Niche separation between the maned wolf (Chrysocyon brachyurus), the crab-eating fox (Dusicyon thous) and the hoary fox (Dusicyon vetulus) in central Brazil. J. Zool. 262:99-106. http://dx.doi.org/10.1017/ S0952836903004473

JENNELlE, C.S., RUNGE, M.C. \& MacKENZIE, D.I. 2002. The use of photographic rates to estimate densities of tigers and other cryptic mammals: a comment on misleading conclusions. Anim. Conserv. 5(2):119-120. http://dx.doi.org/10.1017/S1367943002002160

JESUS, R.M. \& ROLIM, S.G. 2005. Fitossociologia da Mata Atlântica de Tabuleiro. Bol. Téc. SIF 19:1-149.

JOHNSON, D.H. 2008. In Defense of Indices: The Case of Bird Surveys. J. Wildl. Manage. 72:857-868.

KARANTH, K.U. 1995. Estimating tiger (Panthera tigris) populations from camera-trap data using capture-recapture models. Biol. Conserv. 71:333338. http://dx.doi.org/10.1016/0006-3207(94)00057-W

KARANTH, K.U. \& NICHOLS, J.D. 1998. Estimation of tiger densities in India using photographic captures and recaptures. Ecology 79:2852-2862. http://dx.doi.org/10.1890/0012-9658(1998)079[2852:EOTDII]2.0.CO;2

KASPER, C.B., MAZIM, F.D., SOARES, J.B.G., OLIVEIRA, T.G. \& FABIÁN, M.E. 2007. Composição e abundância relativa dos mamíferos de médio e grande porte no Parque Estadual do Turvo, Rio Grande do Sul, Brasil. Rev. Bras. Zool. 24(4):1087-1100. http://dx.doi.org/10.1590/ S0101-81752007000400028

KELLY, M.J. \& HOLUB, E.L. 2008. Camera Trapping of Carnivores: Trap Success Among Camera Types and Across Species, and Habitat Selection by Species, on Salt Pond Mountain, Giles County, Virginia. Northeast. Nat. 15(2):249-262. http://dx.doi.org/10.1656/10926194(2008)15[249:CTOCTS]2.0.CO;2

LARRUCEA, E.S., BRUSSARD, P.F., JAEGER, M.M. \& BARRETT, R.H. 2007. Cameras, coyotes, and the assumption of equal detectability. J Wildl Manage 71(5):1682-1689. http://dx.doi.org/10.2193/2006-407

MacKENZIE, D.I., NICHOLS, J.D., LACHMAN, G.B., DROEGE, S., ROYLE, J.A. \& LANGTIMM, C.A. 2002. Estimating site occupancy rates when detection probabilities are less than one. Ecology 83:22482255. http://dx.doi.org/10.1890/0012-9658(2002)083[2248:ESORWD ]2.0.CO;2

MacKENZIE, D.I. \& ROYLE, J.A. 2005. Designing occupancy studies: general advice and allocating survey effort. J. Appl. Ecol. 42:1105-1114. http://dx.doi.org/10.1111/j.1365-2664.2005.01098.x

O'BRIEN, T.G., KINNAIRD, M.F. \& WIBISONO, H.T. 2003. Crouching tigers, hidden prey: Sumatran tiger and prey populations in a tropical forest landscape. Anim. Conserv. 6(2):131-139. http://dx.doi.org/10.1017/ S1367943003003172

ROVERO, F. \& MARSHALL, A.R. 2009. Camera trapping photographic rate as an index of density in forest ungulates. J. Appl. Ecol. 46:1011-1017. http://dx.doi.org/10.1111/j.1365-2664.2009.01705.x

ROWCLIFFE, J.M., FIELD, J., TURVEY, S.T. \& CARBONE, C. 2008. Estimating animal density using camera traps without the need for individual recognition. J. Appl. Ecol. 45:1228-1236. http://dx.doi. org/10.1111/j.1365-2664.2008.01473.x 
SILVEIRA, L., JACOMO, A.T.A. \& DINIZ-FILHO, J.A.F. 2003. Camera trap, line transect census and track surveys: a comparative evaluation. Biol. Conserv. 114:351-355. http://dx.doi.org/10.1016/S0006-3207(03)00063-6

SILVEIRA, L.F., BEISIEGEL, B.M., CURCIO, F.F., VALDUJO, P.H., DIXO, M., VERDADE, V.K., MATTOX, G.M.T. \& CUNNINGHAM, P.T.M. 2010. Para que servem os inventários de fauna? Estud. Av. 24:173207. http://dx.doi.org/10.1590/S0103-40142010000100015

SMITH, C.D. \& PONTIUS, J.S. 2006. Jackknife Estimator of Species Richness with S-PLUS. Journal of Statistical Software 15:1-12. http:// www.jstatsoft.org/ (último acesso em 22/01/2012).

SRBEK-ARAUJO, A.C. \& CHIARELLO, A.G. 2005. Is camera-trapping an efficient method for surveying mammals in Neotropical forests? A case study in south-eastern Brazil. J. Trop. Ecol. 21(1):121-125. http://dx.doi. org/10.1017/S0266467404001956

SRBEK-ARAUJO, A.C. \& CHIARELLO, A.G. 2007. Armadilhas fotográficas na amostragem de mamíferos: considerações metodológicas e comparação de equipamentos. Rev. Bras. Zool. 24(3):647-656. http://dx.doi. org/10.1590/S0101-81752007000300016

SRBEK-ARAUJO, A.C., SCOSS, L.M., HIRSCH, A. \& CHIARELLO, A.G. 2009. Recent records of the giant-armadillo Priodontes maximus (Kerr, 1792) (Cingulata, Dasypodidae), in the Atlantic Forest of Minas Gerais and Espírito Santo: last refuges of the species in the Atlantic forest? Zoologia 26(3):461-468. http://dx.doi.org/10.1590/S198446702009000300010
TOBLER, M.W., CARRILLO-PERCASTEGUI, S.E., LEITE PITMAN, R., MARES, R. \& POWELL, G. 2008. An evaluation of camera traps for inventorying large- and medium-sized terrestrial rainforest mammals. Anim. Conserv. 11(3):169-178. http://dx.doi.org/10.1111/j.14691795.2008.00169.x

TOMAS, W.M. \& MIRANDA, G.H.B. 2003. Uso de equipamento fotográfico automático em levantamentos populacionais. In Métodos de Estudo em Biologia da Conservação \& Manejo da Vida Silvestre (L.Cullen Junior, R. Rudran \& C. Valladares-Padua, eds.). Editora UFPR, Curitiba, p.243-267.

TROLLE, M. \& KÉRY, M. 2005. Camera-trap study of ocelot and other secretive mammals in the northern Pantanal. Mammalia 69(3-4):405-412. http://dx.doi.org/10.1515/mamm.2005.032

VAUGHAN, T.A., RYAN, J.E. \& CZAPLEWSKI, N.J. 2000. Mammalogy. 4th ed. Thomson Learning Academic Resource Center, Stanford.

VOSS, R.S. \& EMMONS, L. 1996. Mammalian diversity in Neotropical lowland rainforests: a preliminary assessment. Bull. Am. Mus. Nat. Hist. 230:1-115.

WECKEL, M., GIULIANO, W. \& SILVER, S. 2006. Jaguar (Panthera onca) feeding ecology: distribution of predator and prey through time and space. J. Zool. 270:25-30.

YASUDA, M. 2004. Monitoring diversity and abundance of mammals with camera traps: a case study on Mount Tsukuba, central Japan. Mammal Stud. 29:37-46. http://dx.doi.org/10.3106/mammalstudy.29.37 